\title{
Designing of transshipment terminals in the aspect of selected intermodal transport systems
}

\author{
Dariusz Pyza*, and Roland Jachimowski \\ Warsaw University of Technology, Faculty of Transport, Koszykowa 75, 00-662, Warsaw, Poland
}

\begin{abstract}
The article deals with the problem of intermodal terminal designing for selected intermodal transport systems, determined by the type of intermodal transport unit. The purpose of the article is to present a comprehensive methodology for designing intermodal terminals, enabling the assessment of developed design solutions. Specificity of intermodal terminals due to the tasks carried out and their role in the integration of various modes of transport in freight transport was presented. In the following, the general principles and methodology of intermodal terminal design were characterized. Based on that, the conceptual project of the terminal was presented as a case study.
\end{abstract}

\section{Introduction}

The economic development of European Union (EU) countries determines the development of transport, which affects the improvement of economic systems and creates the possibility of moving from solutions based on the use of resources located near their production and consumption to solutions based to the greatest extent on specialization, i.e. the progressing international division of labor [15].

In this aspect, cargo shipments are more and more technologically advanced, so that supply networks are becoming more and more complex, covering more and more regions.

In supply networks, transport plays a crucial role in ensuring the most efficient and effective flow of raw materials, semi-finished products and finished products from the places of their shipment - sending them to the places of their collection - destination. The specificity of the supply network determined by the type of cargo and its transport susceptibility affects the organization of transport and the applied transport technology $[9,13,14$, 15].

The increase in the flow of cargo in economic systems implies the increase in the importance of sustainable transport. This approach requires not only the efficient use of various forms of transport capacity of, but also the search for alternative, environmentally friendly drive sources [5].

In the scope of freight transport, high expectations exist in relation to the development of high-speed railway transport, including intermodal transport. It should be noted, that in many cases these expectations are divergent, between various stakeholders of the intermodal transport market, which include: infrastructure managers and representatives of carriers, intermodal terminal operators, enterprises using transport services - shippers and consignees, as well as representatives of environmental entities, e.g. public administration entities or shippers at other transshipment terminals $[2,9,15,20]$.

An essential element of sustainable transport is forecasting future transport needs, that affect the development of transport networks using intermodality. In this sense, the efficiency of cargo transport is influenced by the multi-branch, integrated transport network, based on a modern and well-designed infrastructure $[15,16]$.

The dynamic development of transport affects both environmental and social costs. The negative impact of transport on the natural environment is caused by high external costs of transport, which include, among others: emissions of harmful exhaust compounds, increased noise levels and accidents.

Reducing the negative transport impact on the environment is one of the priorities of the transport policy of the European Union and the Member Countries. In this aspect, many actions are taken, including among others improving the competitiveness of the railway sector and increasing the share of rail in the distribution of transport tasks or the development of intermodal transport, including support for the creation of intermodal terminals [8].

In Poland, the volume of intermodal transport has been systematically increasing over recent years. In 2018, 17 million tons of cargo were transported by intermodal transport, which is an increase compared to 2017 by $15.6 \%$. The share of intermodal transport in the entire railway transport market measured by the mass of transported cargo reached the level of $6.8 \%$ and was higher by $0.7 \%$ as compared to 2017 . The transportation work performed by the intermodal transport of cargo was at the level of 6.2 billion tkm, which was an increase of $14.8 \%$ compared to 2017 [17].

Corresponding author: dpz@wt.pw.edu.pl 
The presented trends as well as the analysis of transport directions indicate the growing importance of Poland as a transit country connecting East and West.

In this aspect, intermodal terminals, including their modernization and construction of new ones, become important.

The purpose of the article is to present a comprehensive methodology for designing intermodal terminals, enabling the assessment of the developed design solutions.

\section{Intermodal terminals and their specification}

\subsection{Transshipment terminal in the intermodal transport network}

The implementation of transport processes, requires transfer points, where various types of activities related to cargo handling take place.

The transshipment terminals, which aim is to change the type and means of transport play a special role in intermodal transport networks [4].

Intermodal terminal is a spatial object connected with the infrastructure and proper organization, enabling efficient transshipment of intermodal transport units, between means of transport belonging to different modes of transport and performing operations on these units $[10,15]$.

Intermodal terminals are the points of concentration and distribution of cargo in the structures of transport and logistics systems. These points provide transshipment and warehousing services as well as other services related to the distribution of cargo [9].

There are transshipment terminals with various capacities, fulfilling various functions and tasks in the intermodal transport networks.

Because of that, it is possible to distinguishe sea, inland and land intermodal terminals. Land intermodal terminals are located on the railway network with access to road infrastructure and, in some cases, inland waterway infrastructure. Sea (marine) intermodal terminals are located in seaports, where they usually form a part of the sea port. Sea intermodal terminals, due to their functions in intermodal transport, have access to both, rail and road transport infrastructure, and in some cases to inland waterway infrastructure. Inland intermodal terminals are located in inland ports, usually with an access to railway and road infrastructure.

Classification of intermodal terminals can be carried out due to various criteria $[6,9,10]$ :

- type of intermodal transport units,

- means of transport involved in the transport and the delivery of intermodal transport units (ITU) from and to the terminal,

- terminal capacity expressed by the annual turnover of intermodal transport units (TEU),

- functions performed by the terminal in the intermodal transport networks and

- others.
Detailed classification of intermodal terminals with division criteria is presented in Table 1 .

Table 1. Classification of intermodal terminals

\begin{tabular}{|c|c|}
\hline Classification criteria & Terminal type \\
\hline \multirow{3}{*}{$\begin{array}{l}\text { Means of transport involved in } \\
\text { the transport and the delivery of } \\
\text { intermodal transport units from } \\
\text { and to the terminal }\end{array}$} & Sea \\
\hline & Land \\
\hline & Inland \\
\hline \multirow{3}{*}{$\begin{array}{c}\text { Type of intermodal transport } \\
\text { units }\end{array}$} & Container \\
\hline & $\begin{array}{c}\text { Universal } \\
\text { (handles all intermodal transport units) }\end{array}$ \\
\hline & $\begin{array}{l}\text { Selective } \\
\text { (handle selected intermodal transport units) }\end{array}$ \\
\hline \multirow{3}{*}{$\begin{array}{l}\text { Location on the railway } \\
\text { network }\end{array}$} & Rail, rail-road \\
\hline & Sea-rail-road \\
\hline & Sea-rail-road-inland waterway \\
\hline \multirow{3}{*}{ ITU handling system } & Vertical transshipment lo-lo \\
\hline & Horizontal transshipment ro-ro \\
\hline & $\begin{array}{l}\text { Horizontal transshipment ro-ro } \\
\text { and vertical transshipment lo-lo }\end{array}$ \\
\hline
\end{tabular}

The sea terminals provide services of:

- oceanic container vessels: very large (1 million TEU), large $(0.6 \div 1$ million TEU), medium (less than 0.6 million TEU),

- container vessels and semi-containers vessels: medium $(0.1 \div 0.6$ million TEU), small (less than 0.1 million TEU).

$365 / 5000$

Land terminals are divided into: international (hubs) with over 70,000 TEU service, European terminals that support services for $30,000 \div 70,000$ TEU and domestic terminals that support less than 30,000 TEU. Inland water terminals are usually medium-class container terminals servicing over 80,000 TEU and small container terminals with a service volume of less than 80,000 TEU.

Intermodal terminals are not only transshipment hubs, but also service centers for the transport of containerized cargoes that offers additional services [19].

\subsection{Technical requirements for the intermodal terminals}

The functional and spatial system, handling equipment and work organization of the intermodal terminals determine their capacity, i.e. the ability to receive and dispatch a certain amount of cargo per unit of time.

This involves costs, that are a function of the number of cargo handled as well as functional and spatial solutions and the type of equipment used. In this respect, the capacity of the intermodal terminals can be changed by modifying both the functional and spatial layout of the terminals as well as their handling equipment. However, it should be remembered that such activities entail expenditures and affect the total costs of the terminals' operation.

Integration of various forms of transport in the intermodal terminals is perceived as a way to increase the capacity of terminals. At the same time, the terminals' operation costs are reduced. 
The choice of the functional and spatial solutions of the intermodal terminal and its handling equipment should take into account the specifics of the terminal and the number and types of ITU handled per unit of time. In general, functional and spatial solutions include $[9,16]$ :

- rail and road system of the terminal,

- storage and handling yards for containers, swap bodies, semi-trailers, trucks, tractors with semitrailers,

- parking for trucks with ITU waiting for service,

- loading fronts, buildings and technical facilities.

These solutions are determined by the type and the location of the intermodal terminal. Land terminals, marine (sea) and inland terminals have different functional and spatial systems as well as the handling equipment. Further research in this paper is focused on intermodal land terminals located on the railway network.

The operating capability of the intermodal terminal is conditioned by the handling capability of the transport means, storage capacity for intermodal transport units and the capacity of the ITU handling equipment [3]. The minimum requirements for intermodal terminals are regulated by the AGTC agreement. The AGTC agreement specifies the required parameters of the infrastructure of the railway lines and terminals. The guidelines in this respect are prepared by the International Union of Railways - UIC [9, 15].

Efficient ITU service in the terminal is provided by the rail tracks and roads system. Individual groups of tracks should have proper track connections, and the entire track system should be designed with appropriate guidelines and meet all conditions for safe work. The connection of the intermodal terminal with the public road network is provided by the road system, which also allows maneuvers of means of road transport at the terminal depending on the technology of their service. The intermodal terminal road system includes road lanes and maneuver roads $[9,15,16]$.

The ITU storage and handling yards have a double function in the intermodal terminal. They enable both the storage of intermodal transport units and the sorting of intermodal transport units. The storage and handling yards should be designed taking into account technical and technological solutions of the terminal as well as the type and specificity of intermodal transport units. The efficiency of storage and handling yards (areas) is achieved by placing them in the range of the main loading device (handling equipment), thereby limiting the number of loading operations to the necessary minimum $[1,18]$.

Storage and handling yards are designed for ITU such as: semitrailers as well as tracks and tractors with semi-trailers, swap bodies and containers. These types of units can be transported in a Piggyback system, Rolling Highway system as well as in other rail-road systems.

Parking area is usually used as a place where the tractors with semitrailers, trucks with swap bodies as well as the handling equipment, can wait for the operations. Parking areas and storage yards should be designed in accordance with the requirements for internal roads and yards $[9,10,12,15]$.
Loading fronts enable handling of intermodal trains and other means of transport. Loading fronts and storage yards form a loading system, which is an important element of the terminal. The intermodal transport units handling technology at the terminal determines the manner of using individual elements of the loading system $[9,10,11,15,16]$.

A schematic diagram of functional and spatial solutions of the intermodal terminal for the "rolling highway" system is presented in fig. 1.

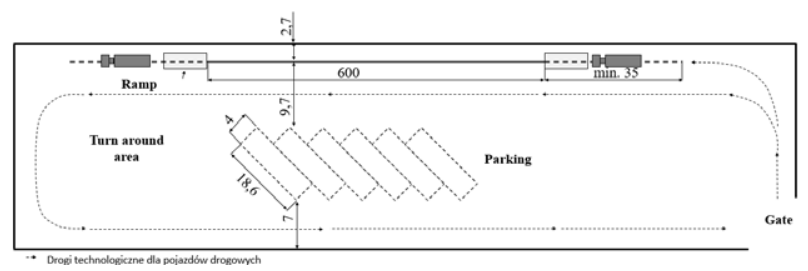

Fig. 1. The example of an intermodal terminal with the „rolling highway" system [9].

Functional and spatial configuration of the terminal is also determined by the handling equipment. The terminals are equipped with handling devices with various technical and operational characteristics as well as appropriate accessories enabling the handling of ITU [9].

\section{Methodology for intermodal terminal designing}

Intermodal terminal designing is an interdisciplinary problem, covering both technical and economic issues. It takes place in terms of process and object design.

Process design is shaping the layout of the terminal, requiring the consideration of the specificity of intermodal transport units and the processes of their flow in the terminal.

The aim of this part of the design is to determine the intermodal terminal layout and the connections between given areas of that layout in the technological aspect.

Object oriented design relies on dimensioning of the terminal, in the aspect of functional and spatial areas defined in the process design. At this stage of a design, parameters that characterize the layout (functional and spatial areas) of the terminal are obtained.

The design procedure for the intermodal terminal is carried out in four design stages (fig 2) [9]:

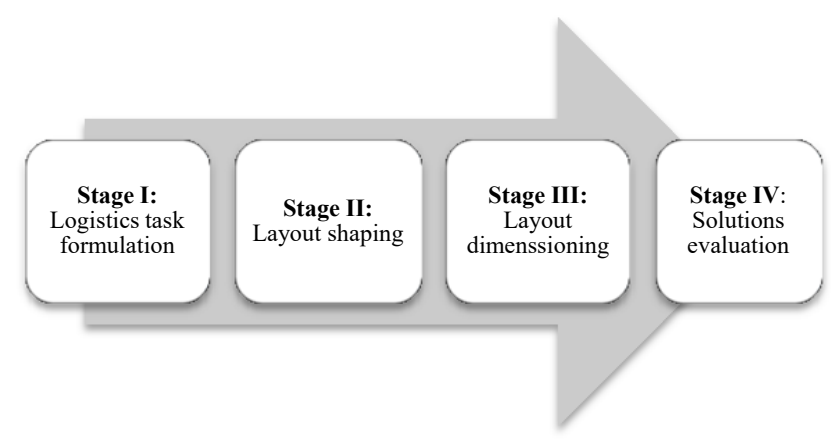

Fig. 2. Intermodal terminal designing stages. 
A. First stage:

- definition of suppliers and recipients and determination of the intermodal transport units' (ITU) transition through by the terminal,

- estimation of the annual and average daily mass of cargo handled by the terminal and the structure of intermodal transport units,

- estimation of the cargo forecasts of the designed terminal and the structure of intermodal transport units in the aspect of the development of intermodal transport systems,

- estimation of the percentage share of ITUs handled in the terminal,

- determination of the average storage time of ITUs.

B. Second stage:

- description of the process of the intermodal transport units flow through the terminal,

- determination of the number of intermodal transport units moved through the terminal in different relations,

- determination of the layout (functional and spatial areas) of the proposed terminal,

- selection of the intermodal transport units storage method in the terminal,

- determination of the intermodal transport units flow cumulation factor.

C. Third stage:

- determination of transport cycles and calculation of transport cycle times for transport of intermodal transport units through the terminal,

- calculation of the daily labor consumption of the intermodal transport units flow through the terminal,

- calculation of the number of handling equipment and human resources necessary to service intermodal transport units, taking into account their type and a human work category,

- calculation of necessary handling equipment and human resources,

- calculation of necessary capacity of trains importing and exporting intermodal transport units,

- determination of the necessary capacity of storage yards,

- calculation of parameters of the loading fronts layout and parameters of communication routes,

- calculation of expenditures and operating costs of the planned intermodal terminal.

D. Fourth stage:

- calculation of assessment indicators for individual design solutions,

- comprehensive evaluation of intermodal terminal project solutions.

The individual stages of terminal design require detailed analyzes in the scope of rationalization of technological processes and equipment as well as layout configuration. Parameterization of input data necessary for terminal design and formal calculations of individual design stages had been described in detail in the authors' work [9].

\section{Intermodal terminal project - case study}

In accordance with the presented methodology of intermodal terminal design and using the formalization of individual design stages, presented in paper [9], a case study of the land intermodal terminal design was presented.

\section{A. Logistics task formulation}

Design assumptions:

- terminal services intermodal transport (loading) units such as: ISO containers (1A, 1B, 1C), semitrailers (NS) and swap bodies (NW);

- terminal services different rail directions: import, export, transit;

- the intermodal transport units (ITU) service technology requires intermediate handling (temporary storage) and direct handling rail carrail car and trailer-rail car;

- the average number of ITU serviced by the terminal per day is presented in table 2 ,

- transshipment operations are performer by rail mounted gantry.

Table 2. Physical ITU number

\begin{tabular}{|c|c|c|c|c|c|c|c|}
\hline & $\mathrm{n}_{\mathrm{N}}$ & $\mathrm{n}_{\mathrm{P}}$ & $\mathrm{n}_{\mathrm{P}-\mathrm{N}}$ & $\mathrm{n}_{\mathrm{S}-\mathrm{S}}$ & $\mathrm{n}_{\mathrm{T}-\mathrm{BP}}$ & $\mathrm{n}_{\mathrm{PN}}$ & $\mathrm{n}_{\mathrm{PP}}$ \\
\hline $1 \mathrm{~A}$ & 25 & 17 & 17 & 12 & 10 & 0 & 8 \\
\hline $1 \mathrm{~B}$ & 25 & 17 & 15 & 10 & 8 & 0 & 8 \\
\hline $1 \mathrm{C}$ & 25 & 17 & 10 & 8 & 3 & 0 & 8 \\
\hline $\mathrm{NW}$ & 5 & 8 & 0 & 0 & 0 & 0 & 0 \\
\hline $\mathrm{NS}$ & 8 & 10 & 0 & 0 & 0 & 0 & 0 \\
\hline
\end{tabular}

where:

$-\mathrm{n}_{\mathrm{N}}-$ number of ITU in the rail transport import

$-\mathrm{n}_{\mathrm{P}}-$ number of ITU in the rail transport export

$-\mathrm{n}_{\mathrm{P}-\mathrm{N}}-$ number of ITU in the rail transport transit

$-\mathrm{n}_{\mathrm{S}-\mathrm{S}}-$ number of ITU in the road transport transit

$-\mathrm{n}_{\mathrm{T}-\mathrm{BP}}-$ number of ITU in the rail transport transit without transshipment

$-\mathrm{n}_{\mathrm{PN}}-$ number of empty ITU in the rail transport export

$-\mathrm{n}_{\mathrm{PP}}-$ number of empty ITU in the rail transport import

In the intermodal terminal, ITUs may undergo several (max. three) transshipment operations.

The percentages of the number of operations for each type of ITU passing through the terminal are shown in table 3 .

Table 3. Percentage number of operations

\begin{tabular}{|c|c|c|c|c|c|c|}
\hline No & $u\left(k o^{N}\right)$ & $u\left(k o^{P}\right)$ & $u\left(k o^{P-N}\right)$ & $u\left(k o^{S-S}\right)$ & $u\left(k o^{P N}\right)$ & $u\left(k o^{P P}\right)$ \\
\hline 1 & 10 & 10 & 20 & 0 & 10 & 10 \\
\hline 2 & 80 & 80 & 80 & 100 & 90 & 90 \\
\hline 3 & 10 & 10 & 0 & 0 & 0 & 0 \\
\hline
\end{tabular}


where:

- $u\left(k o^{N}\right)$ - percentage of the number of operations performed on ITU in rail exports;

- Average storage time: $\mathrm{n}_{\mathrm{N}}-24 \mathrm{~h} ; \mathrm{n}_{\mathrm{P}}-12 \mathrm{~h} ; \mathrm{n}_{\mathrm{P}-\mathrm{N}}-$ $48 \mathrm{~h} ; \mathrm{n}_{\mathrm{S}-\mathrm{s}}-24 \mathrm{~h}$;

- Intermodal transport units flow cumulation factor $-1,3$;

- Rail car - Sdgmnss (434S) - 60' capacity.

\section{B. Shaping and dimensioning of functional/spatial} areas

Assuming that for a long period of time ITUs flow should be balanced, the capacity of trains for containers and swap bodies is:

$$
L M z_{-} N=L M Z_{-} P=285 \mathrm{TEU}
$$

Taking into consideration the possibility of operating two railway lines, the capacity of $L M_{\text {lkier }}$ trains will be 143 TEUs in each direction. With the use of Sdgmnss (434S) cars (rail cars) of a capacity of 3TEU, the demand for cars in one direction (including rail cars utilization factor for semitrailers -1 and 0.9 for containers and swap bodies ) will be: $\mathbf{5 3}$ rail cars for semitrailers and swap bodies and 7 rail cars for semitrailers.

Including the rail car length $(18.34 \mathrm{~m})$, the length of all cars for one rail direction will be $1104 \mathrm{~m}$. It means two trains a day for each direction with a length of 552 $\mathrm{m}(1104 \mathrm{~m}: 2=552 \mathrm{~m})$ without a locomotive.

Then it was assumed that the length of one rail track on the terminal including a train, a locomotive and a certain clearance for inaccurate positioning is $582 \mathrm{~m}$.

For ITU's subjected to intermediate handling, storage yard has to be provided. Taking into account the daily number of containers, swap bodies and semi-trailers moved through the terminal as well as their assumed storage time, the capacity of the storage yard should be :

- 583 TEU for containers

- 19 places for swap bodies

- 25 places for semi-trailers

Assuming that the containers are positioned along the loading tracks, the length of a single storage bay of containers should not exceed $582 \mathrm{~m}$. Therefore, assuming that the length of a single TEU is $6.5 \mathrm{~m}, 582$ / $6.5=89$ TEU can be stored along one storage bay. Assuming the container stacking factor is $\mathrm{k}=2$, than 172 TEU can be stored along one bay. Therefore, the distribution of $582 \mathrm{TEU}$ on the storage yard with a given stacking factor will require $582 / 172=4$ storage bays.

Another element that has to be calculated is a number of cranes performing transshipment operations. In order to calculate that, it was necessary to calculate the number of operations $\left(N_{k o}\right)$. In this case study, including the number of containers, swap bodies and semitrailers that has to be handled in a given direction (some of them are handled directly in the relation rail car - truck, some in the relations: rail car - storage - road truck), the necessary number of operations will be: $N_{k o}=\mathbf{6 4 4}$ operations.

Assuming that the average crane cycle time is 4 $\mathrm{min} /$ operation, daily working hours is $16 \mathrm{~h}$, as well as the working time usage factor of a crane is 0.8 , then the necessary number of cranes $n_{u}$ will be

$$
n_{u}=\frac{N_{k o}}{q_{u}}, q_{u}=\frac{T_{o} \cdot \beta_{u}}{t_{c s} r}
$$

where:

$N_{k o}$ - number of operations

$q_{u}$ - crane daily capacity

$T_{o}$ - crane daily working time (2 shifts, 8hours every shift) $T_{o}=2 \cdot 8 \cdot 60 \mathrm{~min}=960$ minutes

$\beta_{u}$ - working time usage factor of a crane $\beta_{u}=0.8$

$t_{c s ́}$-average crane cycle time $-4 \mathrm{~min} /$ operation

Then:

$$
\begin{gathered}
q_{u}=\frac{960 \text { minutes } \cdot 0.8}{4 \min }=192[\text { operations } / 16 \mathrm{~h} \text { ] } \\
n_{u}=\frac{N_{k o}}{q_{u}}=\frac{644}{192}=3.35=4 \text { cranes }
\end{gathered}
$$

With the use of 4 cranes, their transshipment potential will not be fully utilized, while 3 cranes will be insufficient to service the intermodal terminal at a higher ITUs cumulation than average. Therefore, 4 gantries were accepted.

\section{Solution evaluation}

In order to evaluate the solution it was necessary to calculate expenditures for setting up a terminal as well as its operational cost [7].

Expenditures in the intermodal terminal include those incurred for infrastructure, handling equipment and terminal management systems. In this study we focus on the infrastructure and handling equipment.

In the terminal, handling of intermodal trains requires two loading tracks. It was assumed that the sum of the length of all railway tracks $L_{t k}$ is equal to $2 \cdot 582=1164$ [m], while the cost of $1 \mathrm{~km} c_{t k}$ track is equal to 6000 $[\mathrm{PLN} / \mathrm{m}]$, and therefore the total expenditure on railway tracks is:

$$
E_{t k}=L_{t k} \cdot c_{t k}=1164 \cdot 6000=6984000[\mathrm{PLN}]
$$

In addition, rail tracks are connected by a single rail track crossover. It was assumed that the single crossover cost is $E_{r k}=c_{r k}=380000$ [PLN].

The expenditures for the $E_{p s}$ storage yard are the product of the $P_{p s}$ storage yard surface and the unit cost $c_{p s}$ of the concrete pavement. For the purpose of calculations, it was assumed that $c_{p s}=240[\mathrm{PLN} / \mathrm{m} 2]$, while $P_{p s}=6402 \mathrm{~m} 2$ was determined on the basis of the length and width of storage bays of containers, swap bodies and semi-trailers. Hence, expenditures on the storage yard are:

$$
E_{p s}=P_{p s} \cdot c_{p s}=6402 \cdot 240=1536480[\mathrm{PLN}]
$$

The cranes expenditures $E_{U T}$ are the product of the unit cost $c_{m t}$ for the crane with its assembly and the number $n_{m t}$ of cranes;

$$
E_{U T}=n_{m t} \cdot c_{m t}=4 \cdot 4000000=16000000[\mathrm{PLN}]
$$


It was assumed that the annual costs of railway tracks maintenance $K_{t k}^{R}$ and crossovers $K_{r k}^{R}$ represent $1 \%$ of the expenditure incurred for their purchase $\left(E_{t k}\right.$ and $\left.E_{r k}\right)$, therefore:

$K_{t k}^{R}+K_{r k}^{R}=\left(E_{t k}+E_{r k}\right) \cdot 0.01=73640[$ PLN/year]

For the purpose of a research it was assumed that the cranes maintenance costs represent $10 \%$ of their purchase, therefore:

$$
K_{U T}^{R}=0.1 \cdot 16000000=1600000[\mathrm{PLN} / \text { year }]
$$

Handling equipment operations require the employment of qualified employees. For the purposes of calculations it was assumed that crane operator labor cost is 25 [PLN / h]. It was assumed that each employee works 250 days a year for 8 hours, which gives 2000 hours a year. Therefore, the annual labor costs is:

$$
K_{r}^{R}=25 \cdot 2000 \cdot 8=400000[\mathrm{PLN} / \text { year] }
$$

The aim of this case study was to show, how to calculate the intermodal terminal and what expenditures and costs are the most important while making a decision on terminal layout, its equipment and operations technology. Other expenditures and costs related to terminal administration, terminal management system, as well as other services offered by the terminal were not included in these case study. The detailed analysis on all the element necessary for the terminal evolution can be found in [9].

\section{Conclusion}

Designing intermodal terminals is a multi-stage process that takes into account a number of technical and technological requirements resulting from normative documents.

The layout of the terminal and a technical equipment of the terminal is determined by the specificity of the ITUs and the technological processes. In addition, in many cases, terminal layout solutions are also conditioned by the availability of the land designated for investment.

Therefore, the determination of the size and capacity of terminal layout (functional and spatial areas) and the number of handling equipment necessary to service a given number of ITUs requires a series of calculations. In this aspect, designing should take into account variant solutions, which makes it possible to choose the optimal solution for the adopted assessment criteria.

The growing share of intermodal transport in Poland in the total number of transported cargo causes, that the existing intermodal terminals are very burdened, which means that in the near future they may reach their capacity limit.

Such a phenomenon determines decisions of intermodal terminal operators in the scope of modernization or construction of new terminals. The article proposes an author's approach to a comprehensive intermodal terminal design methodology, in which the area of process and object design is distinguished.

The methodology for designing intermodal terminals presented in the article may be the basis for its use in the design work of designers.

\section{References}

1. Alicke, K., Modeling and optimization of the intermodal terminal Mega Hub. OR Spectrum, 24, pp. 1-17, (2002).

2. Beim M., Mazur B., Soczowka A., Zajdler R., Transport intermodalny $w$ Województwie Wielkopolskim w latach 2004-2014. Przemiany, stan obecny $i$ perspektywy rozwoju. Ekspertyza wykonana na zlecenie Wielkopolskiego Regionalnego Obserwatorium Terytorialnego. Poznań (2015).

3. Boysen, N. and Fliedner, M., Determining crane areas in intermodal transshipment yards: The yard partition problem. European Journal of Operational Research, 204, pp. 336-342, (2010).

4. Carlo, J.H., Vis, F.A., Roodbergen, K.J., Transport operations in container terminals: Literature overview, trends, research directions and classification scheme. European Journal of Operational Research, 236, pp.1-13, (2014).

5. Jachimowski R., Ocena funkcjonowania terminali intermodalnych $w$ aspekcie realizowanych procesów transportowo-przeładunkowych, Oficyna Wydawnicza Politechniki Warszawskiej, (2018) ISBN 9788378147718, $150 \mathrm{~s}$

6. Jachimowski R., Review of transport decision problems in the marine intermodal terminal, Archives of Transport, 44(4), pp. 35-45, 2017

7. Jachimowski R., Selected aspects of costs shaping in the intermodal terminal, Journal of KONES Powertrain and Transport, Institute of Aviation (Aeronautics) BK, Vol. 25, No. 1, (2018)

8. Jachimowski R., Szczepański E., Kłodawski M. [i in.]: Selection of a container storage strategy at the rail-road intermodal terminal as a function of minimization of the energy expenditure of transshipment devices and CO2 emission, w: Annual Set The Environment Protection, vol. 20, ss. 965-988 (2018)

9. Jacyna M., Pyza D., Jachimowski R., Transport intermodalny. Projektowanie terminali przeladunkowych. Wydawnictwo Naukowe PWN, (2017)

10. Jacyna M., Pyza D., Rola intermodalnych terminali przeladunkowych $w$ przewozach kolejowodrogowych. Problemy Kolejnictwa. Oficyna Wydawnicza Politechniki Warszawskiej, Tom 59 Zeszyt 169/2016. Warszawa (2016)

11. Jakubowski L., Technologia prac ładunkowych, Oficyna Wydawnicza Politechniki Warszawskiej, Warszawa (2003) 
12. Poliński J., Rola kolei w transporcie intermodalnym. Oficyna Wydawnicza Politechniki Warszawskiej, Warszawa (2015)

13. Pyza D., Jachimowski R., Modelling of Parcels Transport System. Proceedings of 19th International Scientific Conference. Transport Means 2015. Kaunas University of Technology, Lithuania, (2015)

14. Pyza D., Optimization of transport in distribution systems with restrictions on delivery times. Archives of Transport, Polish Academy of Sciences Committee of Transport, vol. 21, iss. 3-4, Warsaw (2009)

15. Pyza D., Technologie przewozowe $w$ transporcie intermodalnym. Przegląd komunikacyjny, rocznik LXXIV, nr 4/2019. Stowarzyszenie Inżynierów i Techników Komunikacji Rzeczpospolitej Polskiej, (2019)

16. Pyza D., Transport intermodalny - uwarunkowania techniczno-technologiczne, organizacyjne $i$ funkcjonalne, [w:] Wybrane zagadnienia logistyki stosowanej, tom IV, red. J. Feliks, Wydawnictwa AGH, Kraków (2016)

17. Rok 2018 w przewozach intermodalnych. Podsumowanie Prezesa UTK. Urząd Transportu Kolejowego, Warszawa (2019)

18. Steenken, D., Voß, S., and Stahlbock, R., Container Terminal Operation and Operations Research - A Classification and Literature Review. OR Spectrum, 26(1), pp. 3-49, (2004)

19. Szczepański E., Jachimowski R., Kłodawski M., [i in.]: Containers storage strategy at the rail-road intermodal terminal, w: Proceedings of 22nd International Scientific Conference Transport Means. Kaunas University of Technology (2018)

20. Wronka J., Transport intermodalny/kombinowany w polityce transportowej Polski. Przegląd komunikacyjny $\mathrm{nr} \mathbf{8 / 2 0 1 5}$. Stowarzyszenie Inżynierów i Techników Komunikacji Rzeczpospolitej Polskiej, (2015). 